\title{
半球間相互作用と選択的注意に関する検討（I ）
}

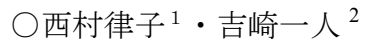 \\ (1 愛知淑徳大学コミュニケーション研究科・2 愛知淑徳大学コミュニケーション学部) \\ Key words: 半球間相互作用 - 選択的注意 - 知覚的負荷
}

本研究は半球間相互作用が選択的注意の働きに及ぼす影響 について検討することが目的である。この問いは，これまで の半球間相互作用研究が各半球の独立した処理資源を想定し て議論されていること（例えば Banich，1998; Friedman \& Polson, 1981）から生じている。

選択的注意に関して近年 Lavie (2005)は, 注意による情報の 選択が初期段階で生じるのか, 後期段階で生じるのかが課題 負荷の高低に応じて配分される処理資源量の多寡によって決 定されるという負荷理論を提案した。その理論の中で彼女は 1)処理資源は有限であり，2)それが使い果たされるまです心゙ ての刺激に自動的に配分されることを前提としている。

そこで本研究では, 課題関連刺激を両視野に呈示し, 両半 球の処理資源が利用可能な事態を設定する。両半球に刺激を 分割した事態での適合性効果を観察することによって, 両半 球での刺激処理が選択的注意に及ぼす影響を検討する。

\section{実 験 1-1}

実験 1-1 は，課題関連刺激を一側視野に呈示した場合でも 負荷理論を支持できるかについて検討した。

方 法 要因計画：ターゲット文字列の知覚的負荷（低負 荷，高負荷）×ターゲットとディストラクターの適合性（一 致, 不一致)。実験参加者 : 右手利きの大学生 16 名。刺激 : ターゲットとディストラクターは “N”，“X”。知覚的負荷の 操作のため “O”, “F”, “H”, “T”をノイズ刺激として使用。 すべて刺激の大きさは視角にして縦 $0.77^{\circ} \times$ 横 0.46- $0.62^{\circ}$ 。 ターゲットは低負荷条件では“O” 2 文字と, 高負荷条件で は“F”，“H”，“T”のうちいずれか 2 文字と共に呈示された （図 1-1）。左右の文字列は凝視点を通る垂直子午線から左右 $2.1^{\circ}$ に, ディストラクターは凝視点を通る垂直子午線上に呈 示され, 凝視点から上, または下に $1.0^{\circ}$ それぞれ呈示された。 手続き：左あるいは右視野に呈示された文字列の中からター ゲット（N, X) を，画面中央の上もしくは下に呈示されるデ イストラクターを無視しながら, 出来るだけ速く正確にキー 押しにより同定することが求められた。4 試行からなるブロ ックを 11 回実施し, 最初のブロックは分析から除外された。

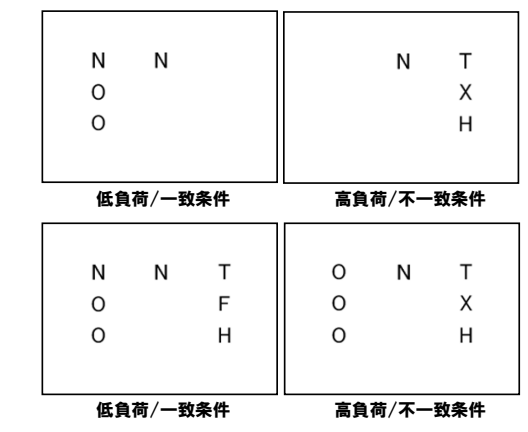

図 1-1。刺激呈示例（上段：実験 1, 下段：実験 2)

結果 と 考察 反応時間を使って，2 要因分散分析を行 ったところ，低負荷条件（630 ms）が高負荷条件（706 ms） よりも有意に反応時間が短く，適合性効果も認められた。交 互作用が有意となり，高負荷条件 $(69 \mathrm{~ms})$ に比べ低負荷条件 (83 ms) で適合性効果量が大きくなることが明らかとなった (図 1-2)。この結果はLavieらの一連の結果と整合的であり，
負荷理論を支持する結果であった。

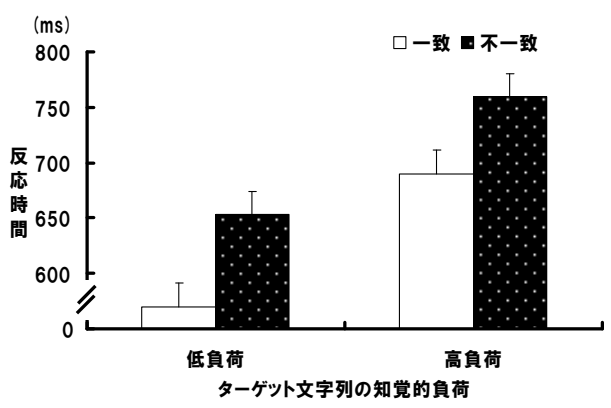

図 1-2. 実験 1-1 の各条件における平均反応時間（バーは標準誤差）

実 験 1-2

実験 1-2 は，両半球に異なる知覚的負荷の文字列を投入す ることで, 両半球での刺激処理が選択的注意に及ぼす影響を 検討した。両半球が独立した処理資源を保持し並列処理を行 っていると仮定すれば，適合性効果量はターゲットが投入さ れた対側半球の文字列の処理負荷に依存すると予測された。 負荷全体を見れば 2 条件間の知覚的負荷の差は，実験 1-1の それに比べ僅かなので, 負荷理論に従えば 2 条件間の全体成 績の差はなくなり，適合性効果量の差もないだろう。

方 法 要因計画：ターゲット文字列の知覚的負荷（低負 荷, 高負荷） ×ターゲットとディストラクターの適合性（一 致, 不一致)。実験参加者：右手利きの大学生 16 名。刺激 : 実験 1-1 と同様。ただし, 低負荷条件ではターゲット文字列 の対側視野に高負荷文字列（“F”，“H”，“T”）が呈示され, 高負荷条件では低負荷文字列 (“O”) が呈示された（図 1-1）。 手続き: 実験 1-1 と同様。ただし, 参加者は左右視野に呈示 される文字列の中のターゲットの同定を求められた。

結果 と 考察 反応時間を使って, 2 要因分散分析を行 ったところ，低負荷条件 $(613 \mathrm{~ms})$ が高負荷条件 $(682 \mathrm{~ms})$ よりも有意に反応時間が短く, 適合性効果も認められた。さ らに交互作用が有意となり, 低負荷条件 $(53 \mathrm{~ms})$ に比べ高負 荷条件 $(84 \mathrm{~ms})$ で適合性効果量が大きくなることが明らかと なった（図 1-3）。つまり，左右視野に呈示された文字列はそ れぞれ投入された半球で処理され，さらにターゲットが入力 されない半球の処理資源の多寡によって適合性効果量が変動 することが明らかとなった。

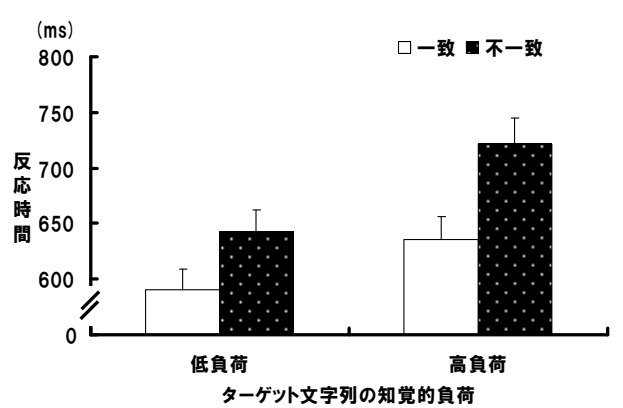

図 1-3．実験 1-2 の各条件における平均反応時間（バーは標準誤差）

本研究は科学研究費補助金(18530575:研究代表者吉崎一人) 並び愛知淑徳大学研究助成の援助を受けた。

(NISHIMURA Ritsuko, YOSHIZAKI Kazuhito) 